\title{
RISK FACTORS OF ACID PEPTIC DISEASE AMONG ADULTS ATTENDING THE GENERAL MEDICINE OUTPATIENT DEPARTMENT OF A TERTIARY CARE INSTITUTION IN SOUTH INDIA- A CROSS SECTIONAL STUDY
}

\author{
Jayasree C. S1, Soumya Rasheed ${ }^{2}$, Sree Lakshmi Menon ${ }^{3}$, Shibla Shajahan 4 , Shireen Majeed ${ }^{5}$, Sona Fazil6, Sofi $S^{7}$, Sruthi L ${ }^{8}$, Surya M. S9
}

1 Professor, Department of Community Medicine, Travancore Medical College, Kollam, Kerala, India.

${ }^{2}$ Final Year MBBS Student, Travancore Medical College, Kollam, Kerala, India.

${ }^{3}$ Final Year MBBS Student, Travancore Medical College, Kollam, Kerala, India.

4Final Year MBBS Student, Travancore Medical College, Kollam, Kerala, India.

5 Final Year MBBS Student, Travancore Medical College, Kollam, Kerala, India.

${ }^{6}$ Final Year MBBS Student, Travancore Medical College, Kollam, Kerala, India.

7Final Year MBBS Student, Travancore Medical College, Kollam, Kerala, India.

${ }^{8}$ Final Year MBBS Student, Travancore Medical College, Kollam, Kerala, India.

${ }^{9}$ Final Year MBBS Student, Travancore Medical College, Kollam, Kerala, India.

\section{BACKGROUND}

ABSTRACT

Acid Peptic Disease is a condition which is widely prevalent among adults. Several individuals especially belonging to the age groups of senior citizens are found to be suffering from this condition. It may manifest as heart burn, nausea, a feeling of gaseous distension of abdomen, decreased appetite, irritability etc. Frequent suffering from these problems will affect the quality of life of the person considerably. Abstaining from certain foods regularly for avoiding the symptoms of this condition may affect the nutritional status of the elderly. On the other hand, young adults may find their work capacity and concentration in work and studies affected by this. Thus, Acid Peptic Disease is an ailment, even though not causing much mortality, can result in considerable morbidity. With an understanding regarding the risk factors of Acid Peptic Disease, life style modifications can be brought about, which can reduce the distress associated with this condition.

Aim of the Study- To evaluate the risk factors for developing acid peptic disease among adults visiting the different departments of Travancore Medical College during the study period.

\section{MATERIALS \& METHODS}

This was a cross sectional study done in Travancore Medical College, which is a tertiary level hospital and teaching institution in Kollam, Kerala. Adults attending the general medicine outpatient department of this medical college were included in the study. A total of 237 subjects were studied.

\section{RESULTS}

Statistically significant association was found for consumption of spicy foods ( $p$ value $<0.001$ ), Non-Steroidal Anti-inflammatory Drugs ( $p$ value $<0.01$ ), intake of hot food and beverages ( $p$ value $<0.01$ ), smoking ( $p$ value $<0.001$ ), alcohol ( $p$ value $<0.001$ ) and emotional stress ( $\mathrm{p}$ value $<0.0 .005$ ) in this study. Regularity of food intake, BMI, regular physical exercise, frequent intake of coffee/tea or vegetarian/non-vegetarian food habits did not show statistically significant association in this study.

\section{CONCLUSION}

Among the various risk factors considered to be associated with acid peptic disease, hot \& highly spicy food, emotional stress, smoking, alcoholism and intake of NSAIDs were significantly related to acid peptic disease in this study group. It follows that a control of these factors by awareness creation supplemented with drugs could bring about considerable improvement in the quality of life of the patients.

\section{KEY WORDS}

Acid Peptic Disease, Adults, Risk Factors.

HOW TO CITE THIS ARTICLE: Jayasree CS, Rasheed S, Menon SL, et al Risk factors of acid peptic disease among adults attending the general medicine outpatient department of a tertiary care institution in South India- a cross sectional study. J. Evolution Med. Dent. Sci. 2018;7(45):4834-4838, DOI: 10.14260/jemds/2018/1077

'Financial or Other Competing Interest': None.

Submission 26-09-2018, Peer Review 20-10-2018,

Acceptance 26-10-2018, Published 05-11-2018.

Corresponding Author:

Dr. Jayasree C.S,

Sreeramgam, A4, Sreeramgam Lane,

Sasthamangalam, P. O.,

Thiruvananthapuram-695010,

Kerala, India.

E-mail: jayasree_cs@yahoo.com

DOI: $10.14260 /$ jemds/2018/1077

\section{BACKGROUND}

An ulcer is a break in the stomach lining, the first part of the small intestine, or sometimes in the lower oesophagus. Around $4 \%$ of the population suffers from peptic ulcers.(1) There is approximately a $10 \%$ lifetime risk of developing a peptic ulcer. Acid peptic disorders (APD) include gastro oesophageal reflux disease (GERD) and peptic ulcer disease (PUD). These are common conditions reported in daily clinical practice. It has been observed that conditions like Irritable Bowel Syndrome (IBS) and functional dyspepsia may mimic these.(1) 
Many of the individuals who suffer from acid peptic disease at any given point of time are affected by the morbidity caused by these. The quality of life is substantially affected by the condition. Prolonged course of disease may result in considerable malnourishment.

The pathogenesis of these disorders involves an imbalance between acid secretion and gastric mucosal defences. Pharmacologic treatment of acid peptic disorders has focused on correcting this imbalance by either improving mucosal defences with drugs such as sucralfate, bismuth, and prostaglandin analogs, neutralizing acid with antacids, or decreasing acid secretion with histamine-2 $\left(\mathrm{H}_{2}\right)$-receptor antagonists, or, more recently, proton pump inhibitors. (2)

The exact frequency of dyspepsia in the general population is difficult to find out because many individuals who have the symptoms do not seek medical care. Of all adults $30-40 \%$ experience symptoms of upper abdominal pain or discomfort but an organic cause is found in only a minority who seek medical care. The rest are grouped as functional dyspepsia. Epigastric pain, burning, postprandial fullness and early satiation are experienced in various degrees by patients.(3) The common risk factors include $\mathrm{H}$. Pylori, non-steroidal anti-inflammatory drugs, tobacco smoking, alcohol, stresses etc. Various journals have been presented showing the relation between acid peptic disease and its risk factors. Type A personality has also been found to be related.(4)

Even though helicobacter pylori is put forward as a factor in the aetiology of dyspepsia, $(1,5)$ this was not included in the study because of the impracticality of doing an endoscopy in the individual patient and establishing the presence of $\mathrm{H}$ pylori.

\section{Objective of the Study}

To find out the risk factors for developing acid peptic disease among adults attending the general medicine outpatient department of Travancore Medical College during the study period.

\section{MATERIALS AND METHODS}

\section{Study Area}

The study was conducted in adults coming to the general medicine outpatient department of Travancore medical college in Kollam district of Kerala. This is a teaching hospital located in the urban area with specialty departments.

\section{Study Period}

September $1^{\text {st }}$ to October $31^{\text {st }} 2017$.

\section{Study Design}

Cross sectional study.

\section{Sample Size}

The prevalence of dyspepsia in hospital patients was found to be $30.4 \%$ in a pilot study conducted by the investigators in the same setting-

$$
\frac{\text { So } 4 p q=4^{*} 30 * 70=237}{d^{*} d 6^{*} 6}
$$

The sample size came to 237

\section{Sampling Method}

Patients above 18 years coming to the general medicine outpatient department were included in the study consecutively, till the required sample size was attained.

\section{A convenient sampling technique was adopted.}

\section{Inclusion Criteria}

Adults visiting the general medicine outpatient department of Travancore Medical College during the study period.

\section{Exclusion criteria}

1. Not giving consent for study

2. Seriously ill patients

3. Individuals who are mentally challenged

\section{Data collection}

The subjects were interviewed by the investigators using a pre-tested structured questionnaire. It was translated into Malayalam and then back translated into English.

Individuals who reported as suffering from any one or more of the following symptoms more than 3 times in the preceding one month were considered as affected by Acid Peptic Disease - Epigastric pain, burning, postprandial fullness, early satiety.

\section{Statistical Analysis}

Data entry was done in Microsoft Excel. The analysis was done using SPSS. Percentages \& frequencies were calculated. Significance testing was done by using Chi square test. A p value $<0.05$ was considered significant.

Due clearance from the Institutional Ethical Committee was obtained and after taking informed written consent from the study subjects, the study was conducted.

\section{RESULTS}

Our study population came to a total of 237. Of them, $111(46.8 \%)$ were males and $121(53.2 \%)$ were females.

The median age of the group was 43 . The number of people above the age of 43 was 116 (48.9\%) and those aged $430 \mathrm{r}$ below came to $121(51.1 \%)$

The distribution with respect to religion was as follows110(6.4\%) Hindus 98 (41.1\%) Muslims and 29(12.3\%0 Christians.

$150(63.3 \%)$ individuals had an education of $10^{\text {th }}$ standard or more. The median income came to Rs. $10,000 /-.111$ people (46.8\%) had an income of Rs. 10,000/- or more per month.

\begin{tabular}{|c|c|c|c|}
\hline Study variable & Frequency & Total & Percentage \\
\hline $\begin{array}{c}\text { Age } \\
\text { <=43 yrs. } \\
\text { >43 yrs. }\end{array}$ & 121 & 237 & 51.1 \\
\hline $\begin{array}{c}\text { Gender } \\
\text { Male }\end{array}$ & 116 & & 48.9 \\
Female & 126 & 237 & 46.8 \\
Religion & 110 & 237 & 46.4 \\
Hindu & 98 & & 41.3 \\
Muslim & 29 & & 12.3 \\
Christian & 150 & 237 & 63.3 \\
\hline Education & 87 & & 36.7 \\
>=10 yrs. of schooling \\
<10 yrs. of schooling
\end{tabular}


Individuals who reported as suffering from any one or more of the following symptoms more than 3 times in the preceding one month were considered as affected by Acid Peptic Disease - Epigastric pain, burning, postprandial fullness and early satiety. According to these criteria, it was found that, out of the 237 subjects 135 suffers from acid peptic disease.

The distribution of factors related to Acid Peptic Disease was analysed. The factors looked for were the food habits (Vegetarian/Non-vegetarian), pain epigastrium, abdominal distension, fullness of stomach, regularity of food intake, preferring very hot food, preferring highly spicy food, nausea following food intake, intake of tea/coffee, alcohol consumption, smoking, Non-Steroidal Anti-Inflammatory Drugs (NSAIDs), BMI, emotional stress, stress at work place, regular physical exercise etc.

\begin{tabular}{|c|c|c|c|}
\hline Risk Factor & Frequency & Total & Percentage \\
\hline $\begin{array}{c}\text { Gastric Pain } \\
\text { Yes } \\
\text { No }\end{array}$ & $\begin{array}{l}135 \\
102\end{array}$ & 237 & $\begin{array}{l}57 \\
43\end{array}$ \\
\hline $\begin{array}{c}\text { Abdominal Distension } \\
\text { Yes } \\
\text { No }\end{array}$ & $\begin{array}{l}105 \\
132\end{array}$ & 237 & $\begin{array}{l}44.3 \\
55.7\end{array}$ \\
\hline $\begin{array}{c}\text { Fullness of Stomach } \\
\text { Yes } \\
\text { No } \\
\end{array}$ & $\begin{array}{l}108 \\
129 \\
\end{array}$ & 237 & $\begin{array}{l}45.6 \\
54.4\end{array}$ \\
\hline $\begin{array}{c}\text { Veg/Non - veg } \\
\text { Veg } \\
\text { Non-veg }\end{array}$ & $\begin{array}{c}56 \\
181\end{array}$ & 237 & $\begin{array}{l}23.6 \\
76.4\end{array}$ \\
\hline $\begin{array}{l}\text { Food Intake } \\
\text { Regular } \\
\text { Irregular }\end{array}$ & $\begin{array}{l}121 \\
116\end{array}$ & 237 & $\begin{array}{l}51.1 \\
48.9\end{array}$ \\
\hline $\begin{array}{c}\text { Skipping Meals } \\
\text { Yes } \\
\text { No } \\
\end{array}$ & $\begin{array}{c}141 \\
96\end{array}$ & 237 & $\begin{array}{l}59.5 \\
40.5 \\
\end{array}$ \\
\hline $\begin{array}{l}\text { Spicy Food } \\
\text { Yes } \\
\text { No }\end{array}$ & $\begin{array}{l}103 \\
134\end{array}$ & 237 & $\begin{array}{l}43.5 \\
56.5\end{array}$ \\
\hline $\begin{array}{c}\text { Intake of Tea/Coffee } \\
<=2 \text { cups/day } \\
>2 \text { cups/day }\end{array}$ & $\begin{array}{l}125 \\
112\end{array}$ & 237 & $\begin{array}{l}52.7 \\
47.3\end{array}$ \\
\hline $\begin{array}{c}\text { Alcohol Consumption } \\
\text { Yes } \\
\text { No } \\
\end{array}$ & $\begin{array}{l}103 \\
134\end{array}$ & 237 & $\begin{array}{l}43.45 \\
56.55\end{array}$ \\
\hline $\begin{array}{l}\text { Smoking } \\
\text { Yes } \\
\text { No }\end{array}$ & $\begin{array}{l}108 \\
129\end{array}$ & 237 & $\begin{array}{l}45.5 \\
54.5\end{array}$ \\
\hline $\begin{array}{l}\text { NSAIDs } \\
\text { Yes } \\
\text { No }\end{array}$ & $\begin{array}{c}154 \\
83 \\
\end{array}$ & 237 & $\begin{array}{l}65 \\
35 \\
\end{array}$ \\
\hline $\begin{array}{c}\text { Job Stress } \\
\text { Sometimes } \\
\text { Always } \\
\end{array}$ & $\begin{array}{l}135 \\
102\end{array}$ & 237 & $\begin{array}{l}57 \\
43 \\
\end{array}$ \\
\hline $\begin{array}{c}\text { Emotional Stress } \\
\text { Yes } \\
\text { No }\end{array}$ & $\begin{array}{c}141 \\
96\end{array}$ & 237 & $\begin{array}{l}59.5 \\
40.5\end{array}$ \\
\hline $\begin{array}{c}\text { BMI } \\
\text { Under weight } \\
\text { Normal } \\
\text { Over weight }\end{array}$ & $\begin{array}{c}4 \\
133 \\
100\end{array}$ & 237 & $\begin{array}{c}1.7 \\
56.1 \\
42.2\end{array}$ \\
\hline $\begin{array}{c}\text { Regular Exercise } \\
\text { Yes } \\
\text { No }\end{array}$ & $\begin{array}{c}182 \\
55\end{array}$ & 237 & $\begin{array}{l}76.8 \\
23.2\end{array}$ \\
\hline $\begin{array}{r}\text { Table 2. Distributio } \\
\text { Disease in th }\end{array}$ & tor: & ed & id Peptic \\
\hline
\end{tabular}

\begin{tabular}{|c|c|c|c|c|c|c|}
\hline $\begin{array}{c}\text { Risk } \\
\text { Factor }\end{array}$ & & APD & No APD & Total & $\begin{array}{c}\text { Chi } \\
\text { square }\end{array}$ & $P$ value \\
\hline $\begin{array}{l}\text { Extremely } \\
\text { hot food } \\
\text { \&drinks }\end{array}$ & $\begin{array}{l}\text { Yes } \\
\text { No }\end{array}$ & $\begin{array}{c}90 \\
(63.8 \%) \\
45 \\
(46.9 \%)\end{array}$ & $\begin{array}{c}51 \\
(36.2 \%) \\
51 \\
(36.2 \%) \\
\end{array}$ & 141 & 6.697 & $\mathrm{P}<0.01$ \\
\hline Spicy food & $\begin{array}{l}\text { Yes } \\
\text { No }\end{array}$ & $\begin{array}{c}73 \\
(70.9 \%) \\
62 \\
(46.3 \%)\end{array}$ & $\begin{array}{c}30 \\
(29.1 \%) \\
72 \\
(53.7 \%) \\
\end{array}$ & $\begin{array}{l}103 \\
134\end{array}$ & 14.382 & $\mathrm{P}<0.001$ \\
\hline $\begin{array}{c}\text { Emotional } \\
\text { Stress }\end{array}$ & $\begin{array}{l}\text { Yes } \\
\text { No }\end{array}$ & $\begin{array}{c}92 \\
(65.24 \%) \\
43 \\
(44.8 \%) \\
\end{array}$ & $\begin{array}{c}49 \\
(34.76 \%) \\
53 \\
(55.2 \%) \\
\end{array}$ & $\begin{array}{l}141 \\
96\end{array}$ & 9.74 & $\mathrm{P}<0.005$ \\
\hline $\begin{array}{l}\text { Alcohol } \\
\text { intake }\end{array}$ & $\begin{array}{l}\text { Yes } \\
\text { No }\end{array}$ & $\begin{array}{c}72 \\
(69.91 \%) \\
63 \\
(47.01 \%)\end{array}$ & $\begin{array}{c}31 \\
(30.09 \%) \\
91 \\
(67.91 \%) \\
\end{array}$ & $\begin{array}{l}103 \\
134\end{array}$ & 21.1 & $\mathrm{P}<0.001$ \\
\hline Smoking & $\begin{array}{l}\text { Yes } \\
\text { No }\end{array}$ & $\begin{array}{c}76 \\
(73.7 \%) \\
59 \\
(38.3 \%) \\
\end{array}$ & \begin{tabular}{|c|}
27 \\
$(26.3 \%)$ \\
95 \\
$(61.7 \%)$ \\
\end{tabular} & $\begin{array}{l}103 \\
154\end{array}$ & 34.3 & $\mathrm{P}<0.001$ \\
\hline NSAIDs & $\begin{array}{l}\text { Yes } \\
\text { No }\end{array}$ & $\begin{array}{c}97(63 \%) \\
38 \\
(45.8 \%)\end{array}$ & $\begin{array}{c}57(37 \%) \\
45 \\
(54.2 \%)\end{array}$ & $\begin{array}{l}154 \\
83\end{array}$ & 6.511 & 0.01 \\
\hline & & ctors $w$ & h Signi & nt & $\operatorname{cin}$ & with \\
\hline
\end{tabular}

Statistically significant association was found between Acid Peptic Disease and risk factors like intake of extremely hot food and drinks, highly spicy food, emotional stress, alcohol intake, smoking and taking NSAIDs.

\section{DISCUSSION}

This study is a cross sectional one conducted in a tertiary care center. Various risk factors for Acid Peptic Disease were studied. A few of them were found to have significant association with this disease.

Many symptoms are reported by individuals affected by acid peptic disease. Even in our study, we have taken pain epigastrium, fullness of stomach and abdominal distension as criteria for the presence of acid peptic disease. In our study, $57 \%$ of the subjects complained of pain epigastrium. $44 \%$ complained that they had abdominal distension and $45 \%$, fullness of stomach. A study conducted by Noorallah Jaber, Marwah Ouda et al show similar prevalence of symptoms pain epigastrium (57\%), abdominal distension (48\%) and $41 \%$ had fullness of stomach. Another study conducted by Sobieraj D M, Coleman SM et al in the US showed the prevalence of symptoms to be $35.2 \%$ (Pain Epigastrium), $24.2 \%$ (Abdominal Distension) and $33.4 \%$ (Fullness of Stomach.)(5)

In our study, we found a relevant association between intake of very hot food and development of acid peptic disease. $(\chi 2=6.6, p<0.01)$.In a study done by Hazra B \& Hazra $\mathrm{J}$ in North Bengal, there was an association between acid peptic disease and preference for hot foods and beverages. In the same study, highly spicy food was also found to be associated with acid peptic disease.(6) In our study also we found a statistically significant association between intake of highly spicy food and acid peptic disease $(\chi 2=14.3$, $\mathrm{p}<0.001)$.More studies like that by Pilichiewicz A $N$ et al have also established a significant relationship between functional dyspepsia and spicy foods. (7) 
Our study found out that $59.5 \%$ of the study subjects suffered from stress. A statistically significant association was established between self-reported emotional stress and acid peptic disease $(\chi 2=9.73, p<0.005)$.Similarly, in a register based cohort study done by Urik Deding, Linda Ejlskov et al using Danish registers and Norh Denmark Health Profile it was found that people with highest level of perceived stress are at least twice at risk of developing acid peptic disease.(8) Another study done by Eun Misong, Hye-Kyung et al found out that high stress was significantly associated with reflux oesophagitis and dyspepsia.(9)

In our study we found that $43.45 \%$ of the subjects consumed alcohol at least occasionally. A significant association was also found between alcohol consumption and acid peptic disease in our study $(\chi 2=21.1, p<0.001)$.A study done by Rosenstock, Jorgensen et al a statistically significant relationship was found.(10) An association which is statistically significant was noted in a study done in Puducherry, South India by V Vijay Ramananand Suresh Kumar Singh.(11) On the other hand, a National Survey done in the U.S by Chou S P found little support for the association of alcohol intake with acid peptic disease.(12)

$45.5 \%$ of the individuals in our study were identified as smokers. Smoking is significantly associated with acid peptic disease in our $\operatorname{study}(\chi 2=34.3, \mathrm{p}<0.001)$.Rosenstock et al in their stud of risk factors in acid peptic disease found that in people with diagnosed $\mathrm{H}$ Pylori infection, tobacco smoking increased the risk of acid peptic disease and development of peptic ulcer.(10) Fu Wei Wang, Ming Shuim et al conducted a similar study in Taiwan to find out that smoking is a independent risk factor in the development of dyspepsia.(13) It has been concluded in a study by Loni Berkowitz, Barbara M Schultz et that the effect of smoking on gastric mucosa causing inflammatory changes is significant.(14)

A large volume of literature is available establishing the relationship between the repeated use of NSAIDS and Acid peptic Disease. We found out that a statistically significant association exists between NSAID use and dyspepsia. $(\chi 2=6.51, p<0.01)$. Similar findings were reported by other workers also. A study by Aafke A Koffe man, Vera E Valkhoff et al established that a significant association exists between NSAID use and acid peptic disease.(15) So also in a study by Tsuyoshi Fujita, Hiromu Kut Sumi et al.(16)Work done by several other investigators have also incriminated the regular use of NSAIDs to be a strong risk factor for acid peptic disease later on leading to peptic ulcer. $(17,18)$

No significant association between regularity of food intake and acid peptic disease was identified in our study done by $\mathrm{F}$ Tovey in Bangladesh too observed the same occurrence.(19)

We found no association between coffee intake of more than 3 cups a day and acid peptic disease. In a study done by Shimamoto, Yamamichi et al. in Japan also failed to find out any such association.(20) In a study by Emelia Papakonstantinon, Ionna Kachribari did not find any significant association between coffee consumption and acid peptic disease.(21)

In our study, we could not find out any relationship between non vegetarian diet and acid peptic disease.(21) But in a comparative study by Jung J G, Kang H W et al among Buddhist priests and general population established a significant association between non vegetarianism and acid peptic disease.(22) Similarly a study by Syed Faisal Zaidihad established a relationship between a non-vegetarian diet and acid peptic disease.(23)

\section{CONCLUSION}

Among the various risk factors considered to be associated with Acid Peptic Disease, hot \& highly spicy food, emotional stress, smoking, alcoholism and intake of NSAIDs were significantly related to Acid Peptic Disease in this study group. It follows that a control of these factors by awareness creation supplemented with drugs, could bring about considerable improvement in the quality of life of the patients.

\section{REFERENCES}

[1] Corazziari E. Definition and Epidemiology of functional gastrointestinal disorders. Best Pract Res Clin Gastroenterol 2004;18(4):613-31.

[2] Rai RR, Gangadhar A, Mayabhate MM. Clinical profiling of patients with Acid Peptic Disorders (APD) in India: a cross-sectional survey of clinicians. Int J Basic Clin Pharmacol 2017;6(1):194-202.

[3] Piotrowicz G, Stepien B, Rydzewska G. Sociodemographic characteristics of patients with diagnosed functional dyspepsia. Prz Gastroenterol 2013;8(6):354-65.

[4] Jaber N, Oudah M, Kowatli A, et al. Dietary and life style factors associated with dyspepsia among preclinical medical students in Ajman, United Arab Emirates. Cent Asian J Glob Health 2016;5(1):192.

[5] Sobieraj DM, Coleman SM, Coleman CI. Prevalence of upper gastrointestinal symptoms - a systematic literature review. Am J Manag Care 2011;17(11):44958.

[6] Hazra B, Hazra J. Epidemiology of peptic ulcer in north Bengal, India. Indian J Public Health 1998;42(4):100-2.

[7] Pilichiewicz AN, Horowitz M, Holtmann GJ, et al. Relationship between symptoms and dietary patterns in patients with functional dyspepsia. Clin Gastroenterol Hepatol 2009;7(3):317-22.

[8] Deding U, Linda Ejlskov L, Grabas MPK, et al. Preceived stress as a risk factor for acid peptic disease registerbased cohort study. BMC Gastroenterol 2016;16:140.

[9] Song EM, Jung HK, Jung JM. The association between reflux esophagitis and psychological stress. Dig Dis Sci 2013;58(2):471-7.

[10] Rosenstock S, Jorgensen T, Bonnevie O, et al. Risk factors for Peptic Ulcer disease: a population-based prospective cohort study comprising 2416 Danish adults. Gut 2003;52(2):186-93.

[11] Ramanan VV, Singh SK. A study on alcohol use and its related health and social problems in rural Puducherry, India. J Family Med Prim Care 2016;5(4):804-8.

[12] Chou SP. An examination of the alcohol consumption and peptic ulcer association-results of a National Survey. Alcohol Clin Exp Res 1994;18(1):149-53.

[13] Fu-Wei W, Ming-Shium T, Guang-Yuan M, et al. Prevalence and Risk factors of symptomatic Peptic Ulcer disease in Taiwan. World J Gastroenterol 2011;17(9):1199-203. 
[14] Berkowitz L, Schultz BM, Salazar GA, et al. Impact of Cigarette smoking on the gastrointestinal tract inflammation: opposing effects in Crohn's disease and ulcerative colitis. Front Immunol 2018;9:74.

[15] Koffeman AR, Valkhoff VE, Celik S, et al. High risk use of over-the-counter non-steroidal anti-inflammatory drugs: a population-based cross-sectional study. $\mathrm{Br} \mathrm{J}$ Gen Pract 2014;64(621):191-8.

[16] Fujita T, Kutsumi H, Sanuki T, et al. Adherence to the preventive strategies for non-steroidal antiinflammatory drug - or low-dose aspirin-induced gastrointestinal injuries. J Gastroenterol 2013;48(5):559-73.

[17] Castellsague J, Riera-Guardia N, Calingaert B, et al. Individual NSAIDs and upper gastrointestinal complications: a systematic review and meta-analysis of observational studies (The SOS) Project. Drug Saf 2012;35(12):1127-46.

[18] Sostres C, Gargallo CJ, Lanas A. Non-steroidal antiinflammatory drugs and upper and lower gastrointestinal mucosal damage. Arthritis Res Ther 2013;15 (Suppl 3):S3.
[19] Tovey F. Peptic ulcer in India and Bangladesh. Gut 1979;20(4):329-47.

[20] Shimamoto T, Yamamichi N, Kodashima S, et al. No association of coffee consumption with gastric ulcer, duodenal ulcer, reflux esophagitis and non-erosive reflux disease: a cross sectional study of 8,013 healthy subjects in Japan. PLOS One 2013;8(6):e65996.

[21] Papakonstantinou E, Kechribari L, Sotirakoglou K, et al. Acute effect of coffee consumption on self-reported gastrointestinal symptoms, blood pressure and stress indies I in healthy individuals. Nutr J 2016;15:26.

[22] Jung JG, Kang HW, Hahn SJ, et al. Vegetarianism as a protective factor for reflux esophsgitis: a retrospective comparative cross sectional study between Buddhist priests and general population. Dig Dis Sci 2013;58(8):2244-52.

[23] Zaidi SF. Helicobacter pylori associated Asian enigma: Does diet deserve distinction? World J Gastrointest Oncol 2016;8(4):341-50. 